\title{
A Review of Identification and Management of Pests and Diseases of Cinnamon (Cinnamomum zeylanicum Blume)
}

\author{
R.H.S. Rajapakse and *K.L.Wasantha Kumara \\ Department of Agricultural Biology, University of Ruhuna, Faculty of Agriculture, Mapalana, \\ Kamburupitiya, Sri Lanka \\ E-mail :rhsrajapakse@yahoo.com,wasantha@agbio.ruh.ac.lk
}

Accepted $2^{\text {nd }}$ September 2007

\begin{abstract}
Cinnamon (Cinnamomum verum Presl., Syn. Cinnamomum zeylanicum Blume) is an important spice crop grown in Sri Lanka and some other countries in Southeast Asia. Although cinnamon is a hardy plant, it is subjected to attack by a variety of insects and microbes. The major insect and mite pests reported in Sri Lanka and other Southeast Asian countries include, a jumping plant louse Trioza cinnamoni (Homoptera: Triozidae), a plant feeding mite Eriophyes boisi (Acarina: Eriophyiidae), Synanthedon spp (Lepidoptera: Sesiidae). The minor insect pests reported are the lepidopteran caterpillars Chilasa clytia, Graphium sarpedon, Orthaga vitialis, Dasychira mendosa, the fruit borer Alcides morio, and the leaf miner Acrocercops spp. The important diseases of cinnamon reported are leaf spot/blight caused by Colletotrichum gloeosporioides and grey leaf spot/blight caused by Pestalotia cinnamomi. Phytopthora cinnamomi causing stripe canker and the pink disease caused by Corticium salmonicolor affecting stems of cinnamon and Phellinus lamaensis causing brown root rot have also aroused some attention by the researchers. The Identification and management strategies adopted for the above pests and diseases are reviewed.
\end{abstract}

Key Words: Cinnammoum verum, pests, diseases, cinnamon

\section{INTRODUCTION}

Cinnamon (Cinnamomum zeylanicum Blume Syn. Cinnamomum verum Presl.) belongs to the family Lauraceae and the group of spice cultivated as a crop. Sri Lanka is responsible for about $70 \%$ of market share of cinnamon in the world. Cinnamon, although a hardy plant, is subjected to attack by a variety of insects, mites and microbes during its development. These pests and diseases are responsible for considerable reduction in the yield of cinnamon bark and also for reducing the quality of other products such as leaf oil, bark oil and root bark oil although, they are not economically significant.

\section{Pests of cinnamon}

Ayyar (1940) first reported that nymphs and adults of Pauropsylla depressa Crawford (Homoptera: Triozidae) produced galls on leaves and shoots of cinnamon in India. Mani (1973) recorded 5 species of insects and mites producing leaf galls and another unknown insect species causing inflorescence galls. Rajapakse and Kulasekera (1982) have listed for the first time in Sri Lanka, the pest fauna associated with cinnamon in Sri Lanka. Devashayam et al. (1997) reported that the major insect pests of cinnamon include cinnamon butterfly Chilasa clytia Lankeswara, Moore and leaf miner Conopomorpha civica in India. The research on insect and mite pests of cinnamon has been carried out at the University of $\mathrm{Ru}-$ huna, Matara, Sri Lanka from 1980 onwards and the major pests infesting cinnamon in Sri Lanka and other South East Countries and their possible control techniques are summarized below.

Trioza cinnamomi: The jumping plant louse (Homoptera:Triozidae)

A jumping plant louse, which is principally associated with the foliage of cinnamon causing leaf galls. Hollis and Martin(1997) reported that 48 species of psylloids are associated with 
lauraceous host plants and a significant majority $(72 \%)$ of these insects is in the family Triozidae. Rajapakse and Kulasekera (1982) reported that $T$. cinnamomi is the most important insect pest of cinnamon in Sri Lanka. Mani (1973) also reported an unknown psyllid also causes formation of galls in cinnamon in India.

\section{Eriophyes boisi (Acarina: Eriophyiidae)}

A mite Eriophyes spp. has also been found to cause morphologically different galls in cinnamon leaves (Mani, 1973). Perera et al. (1985) reported the mite, Eriophyes doctersi Nalepa is also an important pest causing leaf galls in Sri Lanka, and the number of new galls found on young and medium sized leaves were greater than on mature leaves. They also reported that number of new galls was found to increase rapidly after rainfall with the flushing of new leaves. These mite-infested galls can be found on the upper leaf surface and they are pinkish in color at the beginning and become green on maturity. The galls caused by the mite and the psyllid could be separated by examination of the galls morphologically. The females of mites lay eggs singly or in clusters on the upper surface or lower surface on newly emerged tender leaves. The feeding of the nymphs on the sap stimulates the development of pale green to yellowish galls on the leaf surface.

The galls caused by the mites are mostly hypophyllous; ovoid or irregularly conical; cavity with long hairs, with a rugose surface, arising on the leaf blade. The color is greenish or yellowish with the surface somewhat ridged. The lower surface is covered by a thin layer of cells which ruptures to permit the emergence of the adult (Mani, 1973). There may be numerous generations during the year, their length varying according to the season. After the emergence of the adult, the gall dries and turns into dark brown color. The gall cavity is lined by a small closely packed mass of cells lacking chlorophyll which is surrounded by layers of sclerenchyma and parenchyma, also lacking chlorophyll which results in major crop loss.

The leaf galls caused by psyllids are epiphyllous, conical, unilocular, hard yellowishgreen. Galls develop on both sides of the leaf blade, measuring about 2-3 $\mathrm{mm}$ high and 1-2 $\mathrm{mm}$ thick at the base (Mani, 1973). Gall insects generally do little damage to plants because the affected parts are able to carry out photosynthesis with near normal efficiency although the vigor of the plant may be reduced. Rajapakse and Ratnasekera (1997) reported that in a spatial distribution study, the $T$. cinnamoni preferred young, growing incompletely expanded leaves than mature and over mature leaves and there was a positive significant correlation between gall counts and the proportion of young leaves. Gall initiation in cinnamon therefore, appears to be largely restricted to young tender leaves. Rajapakse and Ratnasekera (1997) also reported that $T$. cinnamoni exhibited a strong preference for the top crown level of the plant and this may be due to the preponderance of young leaves in this sector of the tree.

In a study to determine the nutrient composition of various categories of leaves (Rajapakse and Ratnasekera, 1997), it was found that there was no significant relationship of crude protein to abundance of galls but observed significant differences in crude fats in young leaves. This study has verified the relationship between young leaves and crude protein and preference which is well known for other Homoptera (Warren and Moran, 1978). Perera et al. (1985) found the mean oil content of leaves with galls was $18-43 \%$ lower than that of leaves without galls.

The feeding by the mite or the psyllid causes abnormal cell development and the formation of galls. The developing galls enclose the feeding mite or the psyllid.

The severity of mite populations and degree of damage varies with the season in Sri Lanka. Generally losses of leaf surface due to gall formation have an insignificant effect on large mature trees and control measures are unwarranted. Once the injury is evident, it is too late to initiate control measures because the mites and psyllids are already established within the plant. As a result, preventive spray applications of insecticides/miticides are needed to prevent infestation. However, the numbers of effective miticides for controlling eriophyid mites are limited. Two miticides that may be effective include abamectin and bifenthrin, but these pesticides need to be applied before the mite enter the leaves and cause injury.

Biological control of eriophyid mites is very difficult because they live and feed inside galls, which protect them from predators. In addition, there are no known effective natural 
enemies for eriophyid mites. Regular pruning could control the Trioza and Eriophyes infested gall-bearing shoots. When monocrotophos, lannate (methomyl) and methamidiphos applied at top, mid and base of the crop, the application of $30 \mathrm{ml}$ monocrotophos/ $25 \mathrm{~L}$ at 4 days interval resulted in lowest number of galls (Rajapakse and Ratnasekera, 1997). Quinalphos $(0.05 \%)$ or Dimethoate $(0.06 \%)$ are also recommended to control psyllid infested leaves and shoots in India. The above insecticides should be sprayed thrice at 15 days interval during the vegetative bud stage and it will control the homopteran psyllid. If required, repeat the spray at 10-12 day interval. Unlike eriophyid mites, natural enemies often limit the psyllids.

\section{Chilasa clytia Lankeswara, Moore: The common mime (Lepidoptera: Papillionidae)}

Chilasa clytia is a large tailless swallowtail butterfly. This is the only butterfly species in Sri Lanka that is dimorphic for both sexes; there are two different color forms for each sex (van der Poorten and van der Poorten, 2004). The usual flight of the butterfly is slow but when alarmed, it immediately changes the

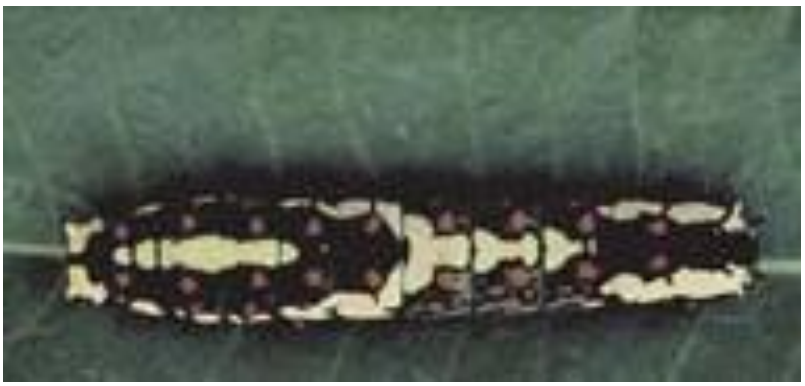

Figure 1: Chilasa clytia larva

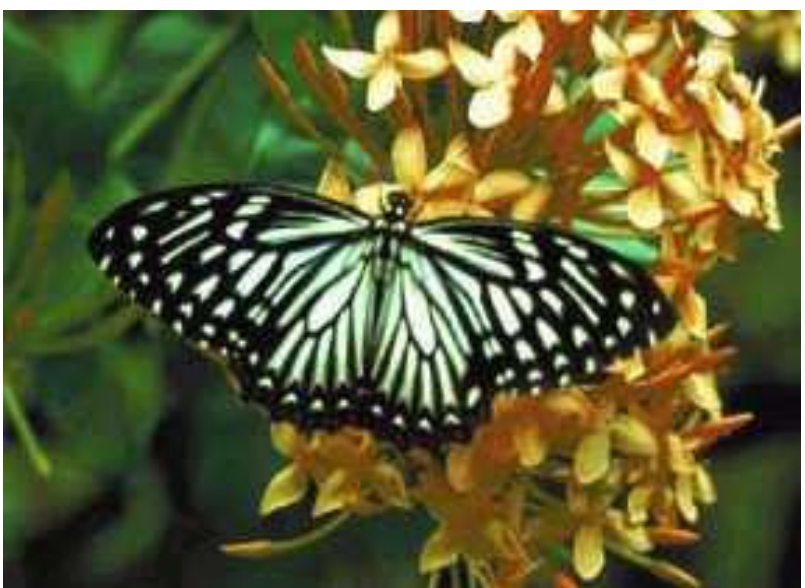

Figure 2: Adult of blue bottle; Graphium sarpedon flight to a fast one. It usually flies within a few feet of the ground when searching for nectar or larval host plants. They may become serious insect pests in young plantations and abundant from December to June. The butterfly lays eggs singly on the upper and lower surfaces of young leaves. The eggs are spherical, waxy looking and orange-yellow in color. The larvae velvety black or dark green (Figure 1) feed on tender and slightly mature leaves; in cases of infestation, the entire plant is defoliated and only midribs of leaves with portions of veins are left behind. The larval period (5 instars) lasts for 11-17 days. The fully-grown larvae are pale yellow with dark stripes on the sides and measures about $2.5 \mathrm{~cm}$ in length. The caterpillars are said to resemble bird droppings (defensive mimicry). The pupae are cylindrical, remarkably well camouflaged and fixed to a branch so as to resemble the end of a broken twig. The pupal period lasts for 11-13 days and the total life cycle 24-36 days. Bell (1912) reported that the moth is seen in large numbers in monsoon months and spends the dry months as pupae.

Eggs are heavily parasitized by the egg parasitoid Telenomus remus. Butani (1983) reported that hand removal of larvae and pupae in light infestations and spraying quinalphos $0.05 \%$ on tender and partly mature leaves in severe infestations can control the pest.

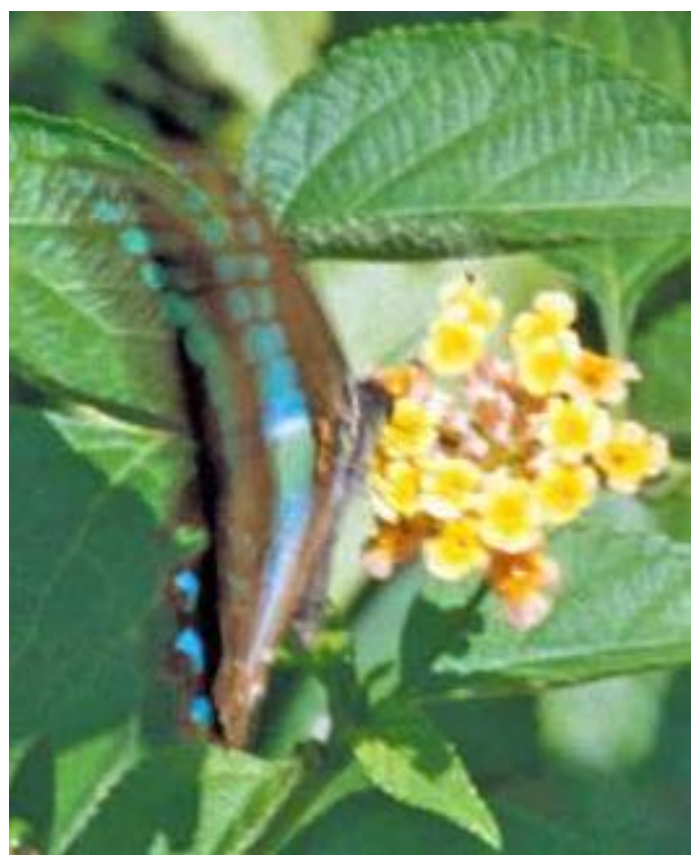

Figure 3: Larva of the Common Jay, Graphium doson 
Graphium sarpedon Teredon: The common blue bottle (Lepidoptera: Papililionidae)

The blue bottles are common (Figure 2) and seen all year around in cinnamon growing areas. In flight, the beautifully contrasting fluorescent blue and black is unmistakable and the sexes are similar. The common blue bottle and Tailed Jay, G. agememnon are the fastest nectar feeders of the butterflies in Sri Lanka (van der Poorten and van der Poorten, 2004). The eggs are laid on the undersurface of the tender leaves and are completely round and smooth and yellow when first lay. Egg period lasts for 5-6 days. The first instar caterpillar is very spiny and of smoke color. They are very sluggish and first keep to the underside of the leaves feeding on them and later seem to favor the mid rib on the upper side of the cinnamon leaves. As they grow older, they become green and quite well concealed by their green camouflage. The larval stage (5 instars) lasts 29-31 days. They pupate on the underside of the leaves, stalks or small branches and the pupal period lasts for 19-20 days. The life cycle is about 59-60 days. The larvae of the Common Jay Graphium doson Doson (Figure 3) is also reported to be feeding on Cinnamon tender leaves (Bell, 1912).

\section{Other minor leaf eating insect pests on cin-} namon

\section{Orthaga vitialis: The leaf and shoot webber (Lepidoptera: Pyralidae)}

The larvae are very active and web the leaves and the terminal shoots into clusters. The webbed cluster of leaves harbor several larvae and they are gregarious at the beginning and feed by scrapping the leaf surface. Pupation takes place within the webbed up cluster for 11 -14 days. The larval period is about 28-30 days. In India, the damage by the shoot and leaf webber, Sorolopha archimedias has been reported as a major pest (Singh, et al., 1978). Inspection of the plantation and pruning the infested clusters is a good cultural control technique.

\section{Euproctis fraterna (Lepidoptera: Lymantrii- dae)}

The larvae of this species feed voraciously on leaves. Initially the larvae scrape the green matter in skeletonization. Later the larvae move in to the other parts of the plant and defoliate. This hairy caterpillar larval stage lasts for 13-29 days and the pupal period lasts for 920 days. The total life cycle lasts for 6-7 weeks.

\section{Dasychira mendosa (Lepidoptera: Lymatrii- dae)}

The larvae of this moth feed on foliage of many plants including cinnamon. Therefore, due to this large host range, the breeding continues throughout the year during which there are probably 5 or 6 generations. The moth, which has pale yellow, hind wings and forewings irregularly patterned with various shades of brown, lays large masses of eggs. The feeding by larvae results in defoliation and the larval period lasts for 21-28 days. The fullygrown hairy larva has a reddish head; the body grayish or yellowish, is striped with red and with long dense dorsal tufts of whitish hairs. They pupate in loose cocoons made of silk and hairs and the pupal period lasts for 11-12 days. Application of Quinalphos $0.05 \%$ would keep most of the caterpillars under check.

\section{Synanthedon spp. (Lepidoptera: Sesiidae)}

The presence of the larvae of this clear wing moth is first reported by Dharmadasa and Jayasinghe (2000) in Sri Lanka. Dying branches, rough bark and insect excreta are good indications that the cinnamon tree is infested with this wood-boring insect. The larvae are 1 inch long at maturity and have a dark brown head and a whitish body that darkens before pupating. These larvae feed on phloem of live trees and tend to mine horizontally. Clear wing moths have long narrow front wings and shorter wider hind wings. The female after mating, deposits her eggs in cracks or wounded areas on bark. Eggs hatch in about 1-4 weeks. The newly emerged larvae bore into the bark, cambium or heartwood. Repeated feeding weakens the branches or kill branches and that may break and fall during windy weather.

Clearwing moths are attracted to treewounds. Pruning of branches frequently exposes the tree base for egg laying. Mature plants can recover from the attack of few lar- 
vae. However, the presence of this pest often indicates that plants have been injured, or neglected. If trees are found infested, insecticides can be applied to the bark, only certain broadspectrum insecticides are effective in preventing borer attack. The contact insecticides Carbaryl, Chlorropyrifos will kill larvae tunneling through the treated bark layer. However, it should be noted that systemic insecticides are ineffective for borer control. The pyrethroid Permithrin is found effective. Selection of insecticides is crucial as the economic product of the cinnamon is the bark. Insecticides are not effective against borer larvae beneath the bark. To be effective, a bark spray must be carefully timed with the egg deposition especially on wounded bark. Complete spray coverage of branch surfaces are necessary for preventive control of borers. There is no need to treat the foliage especially the upper canopy. It is also needed to keep vegetation and mulch away from the base of the tree.

\section{Alcides morio Heller: The cinnamon fruit borer (Coleoptera: Curculionidae)}

The grubs of this curculionid borer feed the inner contents of the seed and tunnels into the cinnamon seeds. The damage is of considerable economic importance since cinnamon is propagated through seeds. Mature grub has a brownish head with a whitish body and attains the length of 8-10 $\mathrm{mm}$. The pupation takes place inside the seed and lasts for 7-9 days. The resultant weevil cuts a circular hole on the seed coat. They are dirty black in color and not active. The females are larger than the males. The longevity of the beetle is 5-7 days.

\section{Acrocercops spp.: The leaf miner (Lepidoptera: Gracillaridae)}

The adult is a tiny silvery moth. The females lay minute flat eggs singly on the lower surface of the leaves close to the mid rib and hatch in about 2-6 days. The pale grey larvae enter the leaf tissue by mining. They feed on the tissues between the upper and lower epidermis of tender leaves resulting in linear mines that end in blister like patches. The infested leaves become crinkle and the mined areas dry up leading to formation of large holes on the leaves. The mined leaves turn pale and curl up and the development of young leaves is retarded. Infesta- tion by leaf miners Conopomorpha civica (Anandaraj et al., 2001) and Phyllocnistis chrysophthalma Meyer has been reported in India (Butani, 1983). Devashayam and Koya (1993) reported that C. civica has infested $20.2 \%$ of the seedlings of cinnamon in Kerala, India. Spraying Quinalphos $0.05 \%$ during the emergence of new flushes found effective in preventing the infestation.

\section{Thalassodes spp. : A looper caterpillar (Lepi doptera: Gracillaridae)}

This is a looper caterpillar found feeding on developing leaves. The larval period lasts for 17-18 days. The larva possessing the color of new shoots and assuming a characteristic pose on the twig is often mistaken for a leaf petiole. The pupal period lasts for 7-8 days.

\section{Olethreutes semiculta (Lepidoptera: Tortri- cidae)}

The larva of this tortricid moth rolls the young leaves together. There are 5 larval instars and the pupation takes place in silken cocoons beneath the folded edge of the leaves. Bhumannavar (1991) reported the presence of the tortricid Sorolopha archimedias (syn. Eudemiopsis archimedias) in cinnamon in South Andaman in India.

Attacus atlas (Lepidoptera: Saturnidae), Agroploce aprobola (Lepidoptera: Encosmidae), the scale Ceroplastes rubens Maskell (Homoptera: Coccidae), the sucking bugs Coptosoma pygmaeum Mont (Heteroptera: Plataspidae) and Leptocentrus obliquus Walker (Homoptera: Membracidae) are found as minor pests in Sri Lanka (Rajapakse and Kulasekera, (1982). The chrysomelid beetles Coenobium lateralis Weise, Cryptocephalus snillus Suffr, Cryptocephalus virgula Suffr and Podagrica badia Harold, were also found feeding on developing leaves and shoots in Sri Lanka (Rajapakse and Kulasekera, (1982). The damage by the larvae of Leucopholis pinguis Burmeister (Coleoptera: Scarabeidae) in nurseries of cinnamon has been reported.

In India, damage by the beetles, a chaffer beetle Popillia complanata and a leaf beetle Singhala helleri has been reported (Singh, et al., 1978). Oecophylla smaragdina F. (Hymen optera: Formicidae) causes nuisance due to the formation of nests from the leaves by the adult 


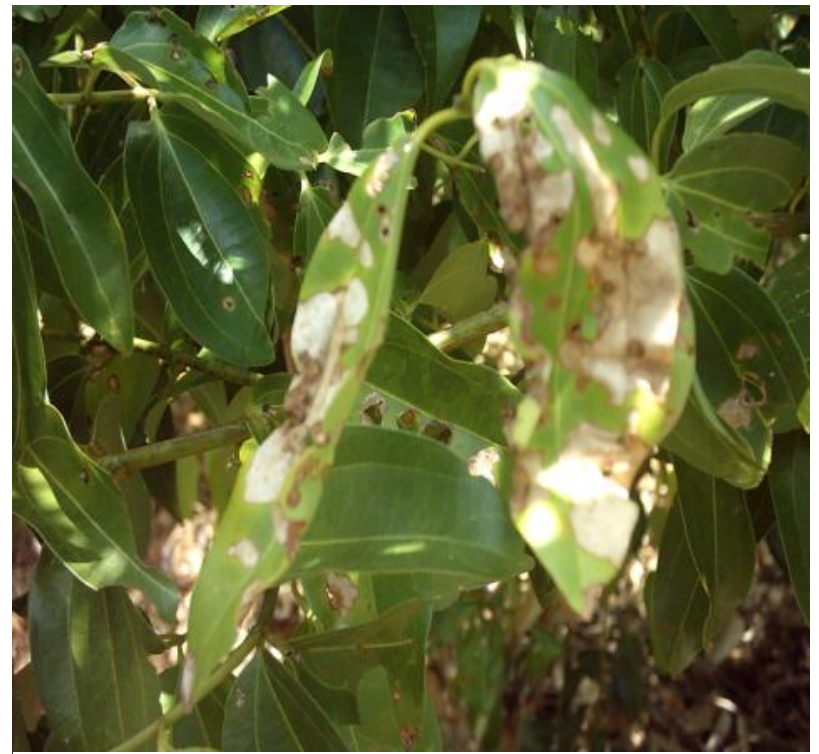

Figure 4: Leaf spot symptoms in Cinnamomum zeylanicum caused by Colletotrichum gloeosporioides

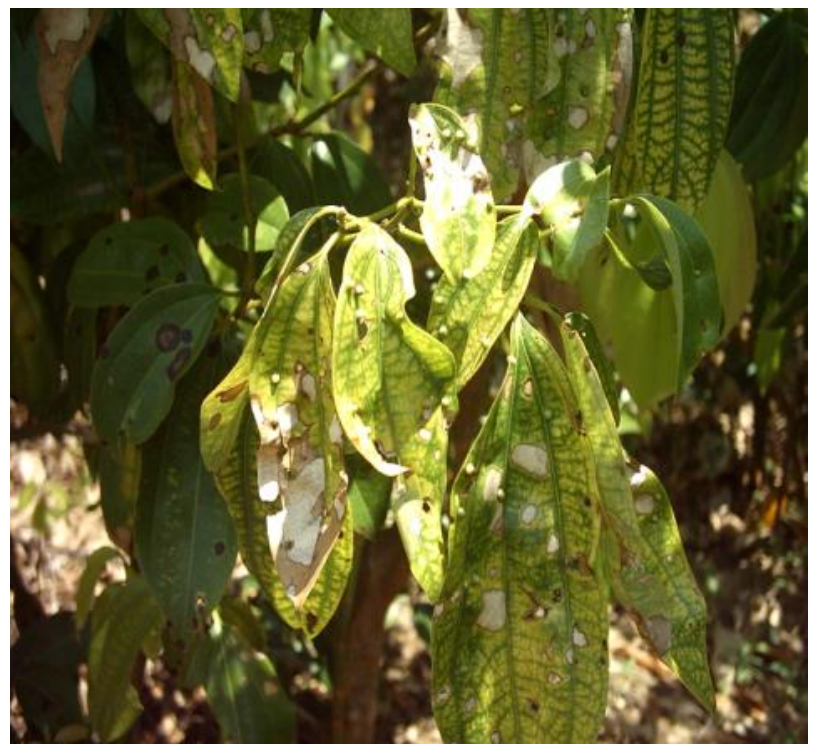

Figure 6: Inter-veinal chlorosis symptoms on leaves due to rough bark disease

ants. Transplanting the nests in a scientific manner will enable the growers to reduce pesticide use as the weaver ants acts like gregarious predators and safeguard the plant from homopteran and lepidopteran insect pests.

\section{Diseases of cinnamon}

Serious diseases reported from cinnamon are less compared to insects and mite damages and also are less economic importance. There has been no significant work done on diseases of cinnamon specially in Sri Lanka although this crop has been under cultivation for centuries.

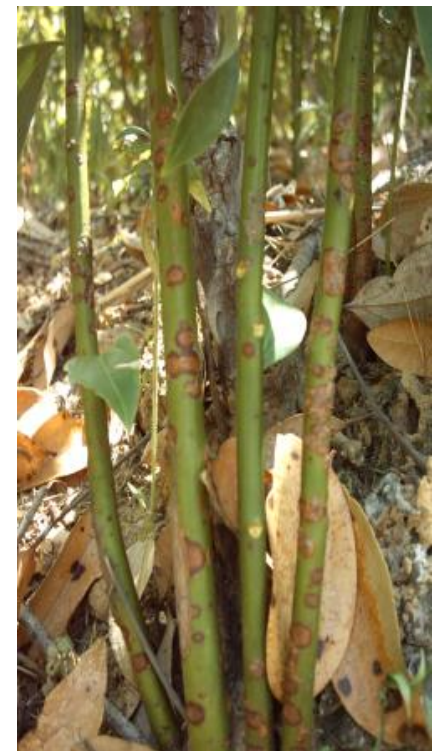

\section{Figure 5: Rough bark disease on stems of cinnamon}

Cinnamon is considered as one of the hardy plants among other spice crops and therefore, chances are comparatively less for severe pathogenic infections. Some of the diseases which have taken considerable attention in south east asian countries have been described.

\section{Foliar diseases}

\section{Leaf spot/blight (Colletotrichum gloesporioid es)}

The leaf spots/blight caused by a fungus Colletotrichum gloeosporioides (Anandaraj and Devashayam, 2004; Kumara, 1999a) is found in almost all cinnamon growing areas in Sri Lanka mainly affecting the foliage. It appears in all growth stages of the plant and the entire foliage can be affected in sever infections. $\mathrm{Ku}-$ mara (1999a) reported 18\% foliar damage due to this disease in Matara, Sri Lanka however, with no significant corrilation detected between cinnmon yield and the disease severity. Considerbly higher disease incidence was observed in lands with high shades, high planting densities, poor weeding, and improper pruning (Kumara, $1999 \mathrm{a}$ and b).

The symptoms in young seedlings include, small brown specks on leaf laminae which, later coalesce to form irregular patches (Figure 4). Small, brownish, leaf spots on older leaves can be seen, specially in shaded areas. These small specks coalesce to form large necrotic blotches giving scorching appearance. Spots 
later become papery with dark brown margins. In other cases the central portion is shed, forming shot hole appearance. Lesions may extend from tip of the leaf or from the margins. At severe infections, lesions may be larger than the half of the leaf. In some seedlings, the infection spreads to the stem causing a dieback (Karunakaran and Nair 1980).

In India, reddish elongated spots were observed arising from the margin and resulting in defoliation (Prakasam, 1991). This also caused shot hole symptoms in later stages. However, the fungus caused this disease has been identified as Phytophthora capsici (Prakasam, 1991). $\mathrm{Fu}$ and Chang (1999) also reported brown to black spots on $C$. verum leaves in Thaiwan. These spots later coalesced and the infected leaves were shed. The pathogen was identified as C. gloeosporioides (Syn. Glomerella cingulata).

Partial drying of the seedlings is another symtom due to this pathogen as reported by Bhat, et al. (1988) in India. In this study, those seedlings yielded C. gloeosporioides (Glomere lla cingulata) and symptoms were reproduced 7 days after inoculation of healthy seedlings.

Copper based fungicides are being used by growers in Sri Lanka to control this disease. For other crops for this type of diseases caused by $C$. gloeosporioides, a range of fungicides have been recommended by the Department of Agriculture, Sri Lanka. Those include, spraying of Chlorothalonil 75\% WP, Carbendazim $50 \%$ WP, Mancozeb $80 \%$ WP or Thiphanatemethyl 70\% WP at 7-10 days intervals. Reducing shades specially during nursery stages may reduce the disease severity.

\section{Grey leaf spots/blight (Pestalotia cinnamomi)}

Pestalotia cinnamomi causing grey blight is also considered as one of the commonest disease of cinnamon (Anonymous, 1996). In India, the disease was reported to be caused by $P$. palmarum on $C$. verum causing foliar damage up to $90 \%$ (Karunakaran et al., 1993). Pestalotia furierea causing similar leaf spot symptoms were reported from Dominican Republic and also from Pakistan (Ciferri, 1926; Ciferri and Fragoso, 1927).

Small yellow brown spots appear on the cinnamon leaves, at first. Later, these spots turn grey with a border and spread to the lamina. Dark acervuli are produced in older lesions appearing as black dots in the centre. This disease can cause severe damage and defoliation. No chemical recommendations are currently available in Sri Lanka.

\section{Black sooty mould (Stenella spp.)}

The disease is not considered as economically important among cinnamon growers and therefore, seldom warrant control measures. Stenella spp. has been reported as the causal agents of the disease.

Blackish growth on the leaf due to sooty mould fungus is the characteristic symptom of the disease. The fungal growth is confined only to the surface and no penetration into the leaf tissues has been observed.

\section{Algal leaf spots (Cephaleuros virescens)}

Another disease which considered as economically less important, is the algal leaf spot disease caused by Cephaleuros virescens. This disease is not currently present very seriously in Sri Lanka and other southeast asian countries although reported in the past.

Orange or brownish coloured spots with velvet appearance are seen on the leaf surface. Leaf spots are rather small in size and enlargement of the spots are also not common or very slow. There is no control measures recommended since the disease is not a serious problem at present.

Three other minor leaf diseases caused by Aecidium cinnamomi, Leptosphaeria spp. and Gloeosporium spp. have been reported but, the extent of damage was not described (Weiss, 2002). Caeoma keralensis causing hypertrophy and witches' broom on young shoots was described by Hosagoudar (1984) and red leaf spots caused by Colletotrichum capsici was recorded by Prakasam (1991) in India.

\section{Stem and root diseases}

\section{Rough bark disease}

One of the important disease in Sri Lanka that has drawn growers attention at present is the rough bark disease. The causal agent is still unidentified. The disease is found in many cinnamon growing areas in Matara district of Sri Lanka and could leads to severe damages to young and mature plants. Kumara (1999b) also 
reported scab-like appearence in cinnamon similar to this, affecting quilling efficiency considerably however, causal organism of the disease was not reported. Sandy soil, slopy lands, long weeding intervals and low dose of fertilizer applications correlate with increasing disease condition (Kumara, 1999b).

Black/brown spots appear on the bark of stems and later become large patches. These spots are surrounded by a dark brown/ black border. Affected area of the bark appeared rough nature giving scab like appearance (Figure 5). These scabby areas extended over the bark with crop maturity reducing yield quality. Inter-veinal chlorosis of leaves of young shoots is common in affected plants (Figure 6). Affected young shoots die in later stages giving heavy yield losses.

Regular removal and destruction of affected bushes/seedlings help to reduce the disease incidence. Selective pruning can also be practiced. There are no chemical recommendations available at present, however, growers practice spraying of $1-2 \%$ Bordeaux mixture to reduce the disease incidence.

\section{Stripe canker (Phytophthora cinnamomi)}

Phytophthora cinnamomi causing stripe canker attacks shoots and young stems of cinnamon. Rands (1922) first reported Phytophthora cinnamomi causing severe losses to forest trees and avocado, as causal agent of stripe canker of $C$. verum. The fungus also affects $C$. campora, C. culitlawan and C. sintok (Ciferri and Fragoso, 1927; Rands, 1922). The fungus Phytophthora cinnamomi from pineapple was also reported pathogenic on cinnamon, but with reduced virulence (Anandaraj and Devasabayam, 2004).

Stripe canker is found on the trunks and branches, particularly of young trees of $C$. verum and $C$. burmannii in Indonesia (Mehrlich, 1934). Vertical stripes are seen on the stems with amber colour exudates at the advancing margins and hardens later. Vertical stripes of dead bark are most numerous near ground level. The disease is prevalent on illdrained soils and causes up to $42 \%$ bark damage. Fungus produces chlamidospores and characterized by non-papilate sporangia which can be obtained by incubating a non-sterile percolate of field soil (Mehrlich, 1934).
Improving soil drainage keeps the disease incidence at a lower level. Phytosanitation such as removal and destruction of affected parts and wound dressing with tar have also been recommended as control measures for this disease (Anandaraj and Devasahayam, 2004).

\section{Pink disease (Corticium salmonicolor B. \& Br.)}

Pink disease caused by Corticium salmonicolor B. \& Br. (syn. C. javanicum) has been reported on cinnamon and considered as an important disease in Sri Lanka, India and Indonesia (Weiss, 2002).

Formation of pale pinkish white encrusted areas on stems or branches is the visible symptoms at the beginning. Later infection spreads destroying bark and finally leading to the death of the smaller shoots. Pathogen also reported to attack mango, jackfruit, custard apple and other fruit trees often grown in the vicinity of cinnamon plantations.

Burning of affected prunings and other plant parts need to be practiced to reduce the disease incidence. No chemicals are recommended for the management of this disease.

\section{Brown root rot (Phellinus lamaensis Murr.)}

This disease is caused by Phellinus lamaensis (Murr.) Heim, damages cinnamon plants to some extent. Chang (1992) reported brown root disease caused by fungus $P$. noxius on $C$. camphora.

Affected roots turn brown. Wilting and death of the aerial portions can be observed in these plants. The fungus was found to affect adjacent shade and ornamental trees such as Dilonix regia, Annona sp. and Prunus sp. (Da Graca et al., 1980).

\section{Other stem and root diseases}

A stem disease caused by Exobasidium cinnamomi has been recorded in Sril Lanka (Weiss, 2002). This disease can also spread in to leaves producing small yellowish concave spots whose underside bears grayish-white spore bodies. Diplidia spp. causing stem blight on young seedlings in the nursery, produce small light brown patches on stems. Later these patches spread and cause eventual death of 
plants.

Other root rots damaging cinnamon plants to some extent, include Rosellinia spp. (root rot) and Leptoporus lignosus (Klot.) Heim (white rot). Rosellinia spp. attack a range of cultivated trees and shrubs covering roots with a network of black mycelium and small white star-like spots under the bark.

\section{ACKNOWLEDGEMENT}

The authors are grateful to the officer in charge of the Cinnamon Research Station, Department of Export Agriculture, Thihagoda, for the assistance and also for granting permission to the students of the Faculty of Agriculture, University of Ruhuna, Matara to perform some of their experiments as partial fulfillment of the requirements of the B.Sc Agriculture degree. Technical assistance by Mr. Namal and Mr. Upali (Department of Agricultural Biology) is also appreciated.

\section{REFERENCES}

Anandaraj, M., Devasahayam, S., Krishnamo orthy, B., Mathew, P.A. and Rema, J. (2001) Cinnamon- Extn.Pamphlet. Indian Inst. Spices Res. Calicut, Kerala, India.

Anandaraj, M. and Devasahayam, S. (2004) Pests and diseases of cinnamon and cassia. In: Cinamon and cassia. (Eds. P. N. Ravindran, K. N. Babu and M. Shylajah), CRC Press, New York, pp.239-258.

Anonymous (1996) Cinnamon; Cultivation and Processing. Technical Bulletin 5, Dept. of Export Agriculture, Ministry of Agriculture, Lands and Forestry, Sri Lanka, pp.7-8.

Ayyar, T.V.R. (1940) Hand Book of economic entomology for South India. 528 p., Govt. Press, Madras, India.

Bell, T. R. (1912) The common butterflies of the plains of India. J. Bombay Nat. Hist. Soc. 21: 517-544.

Bhat, M. N., Hegde, R. K., Hiremath, P. C. and Naid, K. S. (1988) A note on the occurrence of a die-back on cinnamon in Karnataka. Curr. Res., Univ. Agric. Sci., Bangalore. 17(11):153p.

Bhumannavar, B. S. (1991) New records of Sorolopha archimedias on cinnamon in South Andaman. J. Andaman Sci. Assoc. 7 (2): 82-83.
Butani, D. K. (1983) Spices and pest problems 2: Cinnamon. Pesticides 17(9): 32-33.

Chang, T. T. (1992) Decline of some forest trees associated with brown root rot caused by Phellinus noxius, Pl. Pathol. Bull. 1(2): 90-95.

Ciferri, R. (1926) Report on Phytopathology principle of diseases of cultivated plants observed during 1926. SegundoInforme Annual Estac. Nac. Agron. Moca, Republica Dominicana, pp. 36-44.

Ciferri, R. and Fragoso, G. R. (1927) Parasitic and saprophytic fungi of the Dominican Republic (1 $1^{\text {th }}$ Series). Bot. Res. Soc. Espanola Hist. Nat. 27(6): 267-280.

Da Graca, J. V., Vuuren, S. P., and Van (1980) Transmission of avocado sunblotch disease to cinnamon. Pl. Dis. 64: 475p.

Devashayam, S. and Koya, K. M. A. (1993) Additions to the insect fauna associated with tree spices. Entomon 18(1-2):101-102.

Devashayam, S. and Koya, K.M.A., (1997) IPM in spices- challenges for the future. In: Proc. First Naional Symposium on pest management in horticultural crops. (Eds. N. K. K. Kumar and A. Verghese) pp.157164, Indian Institute of Spices Research, Bangalore, India.

Dharmadasa, G. and Jayasinghe, G.G. (2000) A clear wing moth (Synanthidon spp), a new pest damage in cinnamon cultivations and its damaging severity in Sri Lanka. Proc. Sri Lanka Assoc. Adv. Sci. 91p.

Fu, C. H. and Chang, T. T. (1999) Anthracnose of cinnamon. Taiwan J. Forest Sci. 14:513515.

Hollis D. and Martin, J. H. (1997) Jumping plant lice attacking avocado pear trees Persea americana in the New World, with a review of lauraceae feeding among psylloids. Bull. Entomol. Res. 87: 471-480.

Hosagoudar, V. B. (1984) Two interesting fungi on Cinnamomum malabatrum from Idukki, Kerala, India. J. Econ. Taxon. Bot.. 5(1): 209-211.

Karunakaran, P. and Nair, M.C. (1980) Leaf spot and die back disease of Cinnamomum zeylanicum caused by Colletotrichum gloeosporioides. Plant Dis. 64: 220 - 221.

Karunakaran, P., Nair, M.C. and Das, L. (1993) Grey blight disease of cinnamon (Cinnamomum verum Bercht. \& Presl.) leaves. J. Spices and Aromatic Crops 2(12): 66-67. 
Kumara, K.L.W. (1999a) Effect of some agronomic practices on the incidence of leaf spot disease (Colletotrichum gloeosporioides) in cinnamon (Cinnamomum zeylanicum Blume) in southern region of Sri Lanka. SLAAS-University of Ruhuna Seminar on "Pest control in the next millennium", SLAAS, Colombo.

Kumara, K.L.W. (1999b) Study of leaf galls, leaf spots and scab-like condition of cinnamon (Cinnamomum zeylanicum Blume) in Matara District. Proc. Sri Lanka Assoc. Adv. Sci. 65 p., 29 Nov. - 03 December, 1999, Colombo, Sri Lanka.

Mani, M.S. (1973) Plant galls of India. Macmillan Co., India Ltd, New Delhi, India.

Mehrlich, F. P. 1934 Physiologic specialization in Phytophthora species, Phytopathol. 24: 1139-1150.

Perera, H. A. S., Sritharan, R., and Perera, K. P. (1985) Some studies of cinnamon galls in Sri Lanka. Sri Lankan J. Agric. Sci. 22 (1): 23-27.

Prakasam, V. (1991) Red leaf spot of cinnamon in Lower Pulney hills of Tamil Nadu. Indian Cocoa, Arecanut and Spices Journal 14(3): 123.

Rajapakse, R.H.S. and Kulasekera, V. L. (1982) Some observations on insect pests of cinnamon in Sri Lanka. Entomon 7 (2): 221-223.

Rajapakse, R. H. S. and Ratnasekera, D. (1997) Studies on the distribution and control of leaf galls in cinnamon caused by Trioza cinnamoni Boselli in Sri Lanka. Int. J. Tropical Agric. 15(1-4): 53-56.

Rands, R. D. (1922) Stripe canker of cinnamon caused by Phytophthora cinnamomi n. sp., Meded. Inst. Voor Plantenzieketen, 54: 53 p.

Singh, V., O. P. Dubey, Nair, C. P. R., and Pillai, G. B. (1978) Biology and bionomics of insect pests of cinnamon. J. Plant. Crops 6: 24-27.

Van der Poorten, G. and Van der Poorten, N. (2004) Butterflies of Sri Lanka. (Pub G. Van der Poorten), Canada.

Warren, J. W. and Moran, V. C. (1978) The influence of the host plant on the population dynamics of Acissa rusettae (Homoptera: Psyllidae). Ecol. Entomol. 3: 313-321.

Weiss, E. A. (2002) Essential oil crops, CAB international, UK., $191 \mathrm{p}$. 